Portland State University

PDXScholar

$12-2021$

\title{
Partizan: Separating the Human from Propaganda with Film
}

Raymond Hill

Follow this and additional works at: https://pdxscholar.library.pdx.edu/honorstheses

Part of the European History Commons, Film Production Commons, and the Military History Commons

Let us know how access to this document benefits you.

\section{Recommended Citation}

Hill, Raymond, "Partizan: Separating the Human from Propaganda with Film" (2021). University Honors Theses. Paper 1158.

https://doi.org/10.15760/honors.1190

This Thesis is brought to you for free and open access. It has been accepted for inclusion in University Honors Theses by an authorized administrator of PDXScholar. Please contact us if we can make this document more accessible: pdxscholar@pdx.edu. 
Partizan: Separating the Human from Propaganda with Film

by

Raymond Hill

\begin{abstract}
An undergraduate honors thesis submitted in partial fulfillment of the requirements for the degree of

Bachelor of Arts

in

University Honors

and

Film
\end{abstract}

Thesis Advisor

Jennifer Ruth

Portland State University

2021 


\section{Partizan: Separating the Human from Propaganda with Film}

\section{$\underline{\text { Abstract }}$}

The relative protection Americans have for freedom of expression can allow stories to be told that would not be able to be elsewhere. However, telling a story that does not belong to the storyteller and represents people of a different culture or nation can problematize the retelling of events and its perspective. The long-standing rivalry between United States and Russia complicates the matter further, making it difficult to find American film relating to Russia without the inclusion of propaganda and uneducated assumptions in film. Despite these issues, authentic storytelling can provide an informative view of events that the average American has little to no knowledge of, possibly inspiring further interest or personal exploration of the topic. One such topic is the ongoing conflict in Donbas between Ukraine and Russian-supported separatists. In this paper I will intersect film, history, and propaganda. First, I will give a brief description of the importance and my interest, and goals for the topic and I will outline the general history of the conflict. The second part of this paper will give an overview of the complicated relationship American media has with Russian history and the best film techniques to make film authentic. To conclude, I will analyze my film retrospectively, reviewing my current thoughts as I look back on the process of its creation.

\section{$\underline{\text { Introduction }}$}

In my studies to become a film major and history minor at Portland State University, it was impossible to avoid the topics of both warfare and the vaguely defined, but everlasting culture war between the East and West. When it came to both politics and media, nothing seemed to epitomize this conflict like the rivalry between the United States and its allies versus Russia and its allies. Long before college, like many young men I found war films and media, especially relating to the Second World War, especially interesting. From my experience, I 


\section{Partizan: Separating the Human from Propaganda with Film}

understood the USSR to be a place of foreign, despotic customs and people that happened to fight on our side during the first and second World War. As I learned more, I became increasingly interested in how our history and media depicts Russia and why they were and sometimes still are vilified so much as a place and people. The representation of Russians and Soviets in mainstream American war films and the recent discourse about the ongoing RussoUkraine conflict directly inspired this project.

I am a filmmaker, so naturally I wished to express my interest and knowledge of this topic through film. A short narrative film about the war in Donbas, an eastern region of Ukraine bearing the brunt of the conflict, supplements this essay. The contents of this film are not scholarly or primarily for education but exist to inspire those who watch it to do research of their own. It is not the goal of this film and essay to justify a side of the conflict, but to separate the humanist elements from nationalist and imperialist propaganda. It is impossible for me to make claims as I am not someone who has the experience or understanding (especially as an outsider) to conclusively take a stance about such a contested and violent topic. Contemporary information is rarely peer-reviewed or easy to authenticate, further proving the difficulty of making a fair analysis. It is not my goal to make any statement about the conflict other than to explain its complexity can understand why we cannot jump to conclusions easily in such a matter.

\section{Why is this an important topic for us as Americans?}

Foreign conflicts, even those that do not directly include American military participation, are often be connected to American foreign policy. Firearms, explosives, vehicles, mercenaries, political advisory, and money are just some examples of the aid the United States provides to foreign factions in an armed conflict. As one of the world's largest exporter of firearms, it would be difficult to find a conflict that could not be tied back to the United States. Conflicts that may 
Partizan: Separating the Human from Propaganda with Film

seem foreign to Americans such as the Israel-Palestine conflict or the Ukraine-Russia conflict have deep ties to the United States. This makes the representation of any conflict in the media more important, thus providing incentive to learn more about our own country from the struggle of others.

The Russo-Ukraine conflict is particularly interesting because it is an ongoing event that evokes age-old cold war sentiments of East versus West, Freedom versus tyranny, and liberal capitalism versus (in this case former) communism. Although Russia is no longer communist and it is commonly accepted the cold war ended long ago, the uneasy relationship between Russia and the United States still exists in much the same way as it did forty years ago. Although we have never fought the Russians directly in war, numerous proxy wars over the past century placed the two superpowers on the opposite sides of the battlefield. With debate over potential material aid our government has provided to Ukraine, our connection in this matter is more tangible to us than it may seem.

\section{Historical Context}

It would be disingenuous to the history of the people in the borderlands of Ukraine to pass the conflict in Donbas off as simply a war of Western versus Eastern values or a struggle of rugged freedom fighters against Russian imperialism. The roots of the conflict in Donbas are in a history of changing boundaries, populations, and nationalist sentiment. The history of Ukrainian and Russian people is so intertwined, it is critical to locate the time that they became distinct. The $9^{\text {th }}-13^{\text {th }}$ century predecessor to modern Russia, Kievan Rus, was centralized around the location of modern-day Kiev in Ukraine. Throughout the next millennium, the definition of the Ukrainian state becomes obfuscated. It is difficult to find any definitive evidence of a lasting precursor that has substantial similarities in language, peoples, and culture to modern day 


\section{Partizan: Separating the Human from Propaganda with Film}

Ukraine that is distinct from Russia. The clearest moment of early Ukrainian initiative to achieve modern statehood is its war of independence against the Tsardom of Russia in 1917-21. This convoluted narrative of statehood makes the irredentist claims of Ukrainian or Ethnic Russian nationalists difficult to legitimize.

The independence of Ukraine and realization of Ukrainian ethnic identity can be correlated with a new worldwide sense of ethnonationalism occurring in the mid- $19^{\text {th }}$ to early $20^{\text {th }}$ century. Russia in the early $20^{\text {th }}$ century, a large land-based empire, was home to numerous ethnicities and cultures. It is difficult to quantify the exact distribution with any peer reviewed information, but the Russian government conducted a single census in 1897 that can give a rough estimate by associating language spoken to ethnicity. The most prominent languages spoken at the time of the census were Russian (at the time known as Great Russian) at $44.3 \%$ and Ukrainian (at the time known as Little Russian) at 17.8\% (as cited in "Demoscope Weekly", 2014) The rest of the distribution was comprised of numerous linguistic minorities with much smaller percentages.

The results of the census provide an issue when trying to analyze the conflict in the borderlands between Russians and Ukrainians. As can be observed in the 1897 census, Russia was a pluralistic space of many cultures and ethnicities. With the loss of peripheral territories and changes in population, Russia has become more homogenous, but still is home to numerous native non-ethnically Russians. This problematizes the traditional title of Russian through the perspective of contemporary nation-statehood and identity politics, which are arbitrary social constructs. It becomes necessary to look more closely at population shifts and how the people of each region identify themselves, rather than how they are identified through ethnicity or nationality. Zenon Kohut describes in "Origins of the Unity Paradigm: Ukraine and the 


\section{Partizan: Separating the Human from Propaganda with Film}

Construction of Russian National History (1620-1860)" (2001) the difficulty to objectively frame the argument of either side. This is due to the tendency of pro-Russian and pro-Ukrainian historians to view history and belongingness in a radically different context, the former through the lens of state and politics, and the latter through the lens of culture and ethnicity.

The solidification of Ukraine's national identity (language, ethnicity, and culture) occurred mostly during the $20^{\text {th }}$ century. As a part of the Soviet Union, Ukraine existed as the Ukrainian Soviet Socialist Republic. Throughout the lifespan of the USSR, Ukraine's role changed numerous times under the influence of Soviet leadership. One of the early efforts of the USSR was the "nativization" of its republics. This policy encouraged the development of local nationalization, granting a new cultural and linguistic identity to Russian minority populations. One of the regions this effort was applied most significantly was Ukraine. Ukrainian nationalist historians later argued that this effort did not create a new identity for Ukrainians to associate themselves with but was an attempt to re-legitimize the already culturally distinct Ukrainian peoples (Wilson, 1995). These events can certainly be traced to the present-day conflict between Ukraine and Russia. The development of the idea of the nation-state combined with a changing understanding of ethnicity in the Soviet Union has legitimized ethnic strife and the confusion regarding state boundaries.

Complicating the matter further is the distribution of self-identified Russians and Ukrainians in the eastern provinces of modern-day Ukraine. Donbas, annexed by the Russian Empire in the 1600s (Kubicek, 2010) has seen many population shifts in its history. During the post-WWII reconstruction period, Workers traveled to Donbas to bolster infrastructure and dwindling manpower, bringing the Russian population from 0.77 million in 1926 to 2.55 million in 1959. After the nativization of Ukraine in the 1920s, later infrastructure and education pushed 


\section{Partizan: Separating the Human from Propaganda with Film}

back in a re-russification of the region, further strengthening the distinction between Russians and Ukrainians (Wilson, 1995). Cited in Kubicek's chapter "Structure, Agency, and Secessionism in the Soviet Union and Post-Soviet States" of the book Secession as an International Phenomenon (2010), the Soviet Census of 1989 claimed that $66 \%$ of the population of the Donbas region spoke Russian as their native language.

Crimea's status is even more tumultuous. Long after it was first annexed by Russia in 1783, for a brief period after the Russian Civil War Crimea became an independent republic. It was then delegated to independent republic of the Russian SFSR and then an oblast of the Soviet Union. In 1954, the governing of the Crimean Oblast was transferred to the Ukrainian Soviet Socialist Republic, which was likely just a way of restructuring local state authority, as both remained part of the Soviet Union. Throughout the many changes of leadership of the $20^{\text {th }}$ century and the exile of native Crimean Tatars, the population of Crimea became dominated by self-identified native Russian speakers with self-identified Ukrainians and Crimean Tatars a much smaller minority (Wilson, 1995). Kubicek (2010) explains that during the collapse of the USSR “in January 1991, in defiance of [Kiev], Crimean authorities held a referendum in which 93 percent of voters declared their desire to see Crimea awarded autonomous status in the federal structure of the Soviet Union" (p. 283). However, Ukrainian authorities only allowed Crimea to be a semi-autonomous region within the borders of Ukraine.

Donbas, also part of the Ukrainian SSR, had a strong pro-Russian response to the split. Surveys in the 1990s indicated a favor for closer ties with Russia. Many miners and industrial workers, motived by the tumultuous economic situation imposed by market reforms, went on strike in 1993, calling for early elections and economic autonomy. Despite a regional referendum being held in 1994 in which voters indicated a desire for a federal Ukraine and official 


\section{Partizan: Separating the Human from Propaganda with Film}

recognition of the Russian language, the Ukrainian government offered no concessions (Kubicek, 2010). With the independence of Ukraine, the status of Crimea and Donbas was nowhere near solidified. The results of the referendums and the massive local distribution of Russian speakers show that these spaces struggled with their new status as Ukrainian people, a choice made without their consent.

The events leading up to Russia's direct involvement included general political unrest, multiple demonstrations, and a conflict of interest between the heavily ethnic Russian eastern oblasts of Ukraine and the ethnically Russian west. In April of 2014, unmarked pro-Russian militants seized control of government buildings in Donetsk which was soon declared the Donetsk People's Republic. Throughout the summer of 2014 intense fighting would spread throughout many areas of Donbas and despite multiple ceasefires and attempts at ending the violence in Donbas, conflicts are still reported by news outlets in the region today. In Crimea, the situation was far less confrontational. In late 2014, after numerous pro-Russian demonstrations in Sevastopol, unmarked soldiers quickly took over the parliament and captured strategic sites throughout Crimea, installing a pro-Russian government in Crimea. After only two days after declaring independence from Ukraine, Crimea was formally incorporated into the Russian Federation (Ostrovsky, 2014), with only a handful of civilian casualties, although it is difficult to find an authoritative source on this information.

What should be evident from this summary of events is that the conflict between Russia and Ukraine is not as clear-cut as it may seem. The transformation of Russia from a pluralistic space home to many ethnic minorities to multiple spaces of strong national sentiment is impossible to occur without conflict. History has shown that the sudden implementation of the idea that a certain space belongs to a certain ethnicity or culture (especially when it was once 
Partizan: Separating the Human from Propaganda with Film

home to a melting pot of different peoples) is extremely problematic and has been the cause for numerous atrocities as seen in former Yugoslavia, the Caucuses, and Europe during the Second World War. People are being used as justifications for land ownership and land ownership is being used as justification for the ruling of peoples who may want their independence. There is no statement to be made about who is in the right in this situation. What matters is that people are being used as pawns in a game of socially constructed nation-statehood.

\section{$\underline{\text { Film About Russia }}$}

The long-running conflict of values between Russia and the United States is reflected in our depiction of wars involving them in film, often suffering from little historical knowledge and overbearing propaganda. Often simply a generic foe or neutral force seen in entertainment such as the James Bond or Mission Impossible mission impossible films, there are a few circumstanced where they act as the primary protagonists. A contemporary example of this would be Enemy at the Gates (Mandalay Pictures, 2001). This film follows the story of the famous Second World War Soviet sniper Vasily Zaitsev, but takes many liberties not only with the plot, but with the depiction of the battle of Stalingrad itself. From the inaccuracies and assumptions regarding Stalin's order No.227 "not one step back", showing a merciless slaughter of retreating friendly conscripts, to the Soviet forces shown as little more than a poorly trained and equipped infantry with no air or tank support, there is little about the film that bears much of a resemblance to the reality of the situation. Many details relating to the time and setting of the film are also incorrect, from period-inaccurate infantry equipment to even the usage of an anachronistic Soviet national anthem.

Because of the problems inherent to American films when it comes to depicting Russia, I instead took inspiration from Russian and Eastern European films for this project. The 


\section{Partizan: Separating the Human from Propaganda with Film}

Soviet/Belarusian film Come and See (Mosfilm \& Belarusfilm, 1985) and the Hungarian film Son of Saul (Laokoon Filmgroup, 2015) are two primary examples that served as reference during my production. Although Russian films are certainly not devoid of propaganda or censorship, the lack of traditional plot-oriented structure and straightforward film style provided by these examples give a more immersive and authentic experience for the viewer. The former's sound design and depiction of desperation and the latter's neorealist cinematic techniques were of particular interest to me.

Neorealism is a film movement associated primarily with post-Second World War Italian film that dealt with poverty, desolation, and oppression. The films were often made outside of studios with lower budgets, making the content of the film more authentic (Thompson, 2010). This style is reflected and emulated by past and present filmmakers around the world. Its simplicity and candid nature allow a film to avoid spoiling a topic with unnecessary conventions. Neorealist films tend to focus on the human aspect of an event, basing the action around the choices of the character rather than the character around the conventions of the plot. This was an incredibly important element of this project as I wished to place the human in the situation as the primary driving force for the film's perspective.

\section{My Film}

My short follows a pro-Russian soldier in an unspecified region of Ukraine, likely in the Donbas region during the 2014 invasion. After being wounded and separated from his unit, he must fight his way to safety through Ukrainian partisans. The partisans are neither well equipped nor well-trained and are easily dispatched by the Russian-trained soldier. The main adversary for the soldier, antagonist if you will, is an unseen machine gun, firing down on him from an entrenched position. After locating the machine gun, the soldier dispatches it with a grenade, 


\section{Partizan: Separating the Human from Propaganda with Film}

making the horrifying revelation only too late that it was manned by a young teenager. The action is shown from the perspective of the Russian soldier because of my interest in the American depiction of Russia, but also to highlight the complicated moral quandary faced by Russians as they fight people who once were part of the same state. The film's plot takes inspiration from several recorded real-life events involving the Russian army. As mentioned before, this film is not meant to inform as a documentary would but bring to light an unknown subject and perhaps inspire more research on behalf of the viewer. To be careful of misrepresenting unknown details or events, the film is not about a specific conflict within the war but is meant to represent any part of it. I chose to do this to avoid entrenching the very brief narrative in minutia and confusing facts.

I wrote the screenplay, directed the shooting of the film, and completed the edit. There are numerous other people who have helped create the project, but I have made sure to maintain creative responsibility. Camera techniques keep the audience close to the action, but also are simply framed to avoid confusion or weighted imagery. The intention is to make a film that does not interfere with the viewers' perception of the content, making the experience as honest as possible. The soldier is the only on-screen character with significant dialogue, as the film is from his perspective, but also maintains a distance from his thoughts and feelings. The audience is meant to empathize, but not sympathize with the soldier's motivations or movement he belongs to. The audience is simply seeing the action from his perspective. I chose to do this because as an outsider I do not presume to know the feelings and exact details of the people involved, and instead wish him to represent any pro-Russian soldier, or even pro-Ukrainian soldier, as they both are placed in similar situations. Instead of an educated biased approach, I wished to take an educated unbiased approach, which may seem counterproductive, but when so few Americans 


\section{Partizan: Separating the Human from Propaganda with Film}

know anything about this subject, it is the best route to take to avoid bogging the message in excessive details that would confuse the casual viewer.

To create the film I found numerous sources, many of which could not be definitively verified, meaning I had to self-review sources through cross referencing. The difficulty of circumnavigating propaganda from any side of the conflict was difficult, limiting my choices for sources on the conflict. For basic knowledge surrounding the conflict, I watched a Vice News documentary about the annexation of Crimea which was filmed as it occurred. The plot of the short film is inspired by two news stories: one of a fallen Russian soldier in Syria who sacrifices himself to destroy the enemy and another a recovered helmet camera recording of a Ukrainian patrol decimated by Russian troops (Smitsky, 2014). To make sure the equipment used by the characters was appropriate, I cross-referenced real footage of the conflict with the video game Escape from Tarkov (Battlestate Games, 2017), which depicts a fictional conflict in contemporary Russia between the military and various private military groups. This allowed me to find the names of equipment in both Russian and English as well as get an idea of how it functions in real life. The developers of the game have a primary focus of making every aspect of the game authentic to its real-life counterpart as stated in its terms of service and shown by their behind-the-scenes videos of them utilizing real military materiel as a basis for game functions.

The title Partizan comes from the word partisan and a type of sniper suit worn by Russian special forces and FSB. It is often adorned with a camouflage pattern inspired by a Nazi German design known as Oakleaf. The suit and use of the camouflage have no nationalist or Nazi political connections, but I found its history to be interesting, reflecting the changes in associations that occur when different people on different sides of a conflict take something for their own. 


\section{Partizan: Separating the Human from Propaganda with Film}

\section{$\underline{\text { Self-Review }}$}

I think I was as authentic as I could have been with the resources and knowledge, I had at the time of creating my film. Resources and time were the primary limiting factors of its scale, both in quantity and quality, but later developments and revelations of the situation in Ukraine have changed my perspective. If I had an unlimited budget, I would have made a feature-length film that follows fighters on both the side of the Ukrainians and the Russians. To the extent of creating a neo-realist film that is relatively authentic, engaging, and open to interpretation, I believe I succeeded. It is impossible as of now to quantify my success, as only a few people have seen the film and mostly for the purposes of quality control rather than casual viewership. In the future when I submit this film to festivals, I hope to have the opportunity to speak with those who watch it to ask their interpretation of the film and what their presumptions and level of knowledge may be about the Russo-Ukraine conflict. 


\section{Partizan: Separating the Human from Propaganda with Film}

\section{References}

Buyanov, N. (2017) Escape from Tarkov (PC version) [Video game]. Battlestate Games.

A Russian video game focusing on the collapse of Russian government in an isolated region and the resulting conflict. The studio prides itself in the accurate depiction of Russian equipment, weapons, and miscellaneous gear. Although I did not use this as a resource alone, it provided a simple method of cross-referencing the names of military materiel seen in combat footage and photographs from the Crimea region.

Klimov, E. (Director). Come and See [Film]. Mosfilm \& Belarusfilm.

Kohut, Z. E. (2001). Origins of the unity paradigm: Ukraine and the construction of Russian National History (1620s-1860s). Eighteenth-Century Studies, 35(1), 70-76. https://doi.org/10.1353/ecs.2001.0060

Kubicek, P. (2010). Structure, Agency, and Secessionism in the Soviet Union and Post-Soviet States. In Secession as an international phenomenon from America's Civil War to contemporary separatist movements (pp. 277-294). essay, University of Georgia Press.

Nemes, L. (Director). Son of Saul [Film]. Laokoon Filmgroup.

A Hungarian film about the holocaust, this film provided inspiration for the neo-realist cinematic techniques I used in my short. Unrelated to the topic of war in Ukraine, this film provides an intimate look at personal emotional and physical struggle in the face of mortal danger.

Ostrovsky, S. (Host). (2014). Russian Roulette in Ukraine [Video file]. Retrieved from https://www.youtube.com/watch?v=TNKsLlK52ss\&list=PLw613M86o5o7a0FGlPRdt47xiD iggbNsZ\&index $=1$

This series by Vice News explores the annexation of Crimea as it occurs. The host interviews combatants on both sides to understand the motivations they have for fighting for, or against an independent Ukraine. At the time, Russia was still feigning innocence in the invasion, making the situation confusing for the Ukrainian army and its allies. Rural combat between militias and the army provided inspiration for the content of the film.

Smitsky, J. (Archive Curator). (2014). Ukrainian sabotage-recon group failed operation [Video file] Retrieved from https://www.youtube.com/watch?v=deM6R96hnf0

This website/YouTube channel uploads archived footage from the Russia-Ukraine conflict in Donbass. Due to the graphic and revealing nature of this footage, it can be difficult to find the original source. In this particular collection of footage, a group of Ukrainian soldiers attempt a raid behind enemy lines but are quickly discovered and dispatched by Russian forces. The helmet-cam perspective and video from both sides shows the brutality of the war and the lack of equipment and organization for the Ukrainian forces. 


\section{Partizan: Separating the Human from Propaganda with Film}

Thompson, K., Bordwell, D., \& Smith, J. (2010). In Film history an introduction (3rd ed., pp. 330-331). essay, McGraw Hill Education.

Vishnevsky Institute of Demography. (2014). Demoscope weekly. Retrieved December 9, 2021, from https://www.hse.ru/en/demo/demoscope.

Wilson, A. (1995). The Donbas between Ukraine and Russia: The use of history in political disputes. Journal of Contemporary History, 30(2), 265-289. https://doi.org/10.1177/002200949503000204 